SVU- International Journal of Veterinary Sciences, 3 (2): 14-24, 2020.

Print ISSN: 2535-1826

\title{
In vitro effect of zinc oxide nanoparticles on Staphylococcus aureus isolated from Layer Chickens
}

Fatma M. Mohamed*1, Aml A.M. Bakheet', Ali A. Othman², Usama T. Mahmoud ${ }^{3}$, Omar A. Amen ${ }^{4}$

${ }^{1}$ Poultry Diseases, Assiut Regional Laboratory, Animal Health Research Institute, Agricultural Research Center (ARC), Egypt, ${ }^{2}$ Physics Department, Faculty of Science, Assiut University 71515, Assiut- Egypt., ${ }^{3}$ Department of Animal and Poultry Behaviour and Management, Faculty of Veterinary Medicine, Assiut University 71515, Assiut-Egypt., ${ }^{4}$ Department of Poultry Diseases, Faculty of Veterinary Medicine, Assiut University, 71526, Assiut-Egypt.

\section{Abstract}

This study aimed to evaluate the antibacterial activity of zinc oxide nanoparticles (ZnO-NPs) on Staphylococcus aureus (S. aureus) isolated from layer chickens using minimum inhibitory concentration test (MIC). Samples $(n=120)$ from the hock joints and livers of layers were collected under aseptic conditions from diseased and freshly dead chicken layers from different private farms in Assyut Governorate. Twenty-nine isolates of Staphylococci were recovered from 120 collected samples, with a prevalence rate of $24.16 \%$. Nineteen $(65.5 \%)$ of these 29 isolates were coagulase negative and ten $(34.5 \%)$ were coagulase positive. The coagulase positive strains (CPS) were further analyzed using PCR. Our PCR results confirmed that these isolates are S. aureus as they encoded (clfA gene), while 6 isolates only were Methicillin Resistant Staphylococcus Aureus (MRSA) as they harbored mecA gene. Nine isolates of the demonstrated S. aureus displayed variable antibiotic sensitivity patterns in MIC assays against $\mathrm{ZnO}-\mathrm{NPs}$ and some selected antibiotics. Our data showed that, $\mathrm{ZnO}-$ NPs have the potential antibacterial effect against majority of the isolates compared to other tested antibiotics.

Keywords: Staphylococcus aureus, sensitivity tests (MIC), layer chicken, zinc oxide nanoparticles.

DOI: $10.21608 / \mathrm{svu} .2020 .28106 .1047$

Received: April 17, $2020 \quad$ Accepted: May 2, 2020

*Corresponding Author: Fatma M. Mohamed

Published: May 7, 2020

E-mail: elzuhry@yahoo.com

Citation: In vitro effect of zinc oxide nanoparticles on Staphylococcus aureus isolated from Layer Chickens. SVU-IJVS 2020: 3 (2): 14-24.

Copyright: @ Mohamed et al., This is an open access article distributed under the terms of the creative common attribution license, which permits unrestricted use, distribution and reproduction in any medium provided the original author and source are created.

Competing interest: The authors have declared that no competing interest exists. 


\section{Introduction}

In poultry, the disease conditions associated with staphylococcosis are a worldwide problem and vary with the site and route of infection in hatchery and poultry farms, and can infect the bones, joints, tendon sheaths, skin, sternal bursa, navel, and yolk sac through breakage of the skin and mucosal membrane of the birds, especially immunocompromised ones which are often more prone to staphylococcal infections. Once in the host, $S$. aureus invades the metaphyseal area of the nearest joint, which leads to osteomyelitis and become localized within that joint (Onaolapo et al., 2017). However, if $S$. aureus invades the bloodstream, it causes systemic infection in multiple organs, thereby causing economic losses, which accrued as a result of decreased weight gain, decreased egg production, lameness, mortality, and condemnation at slaughter (Andreasen, 2003). Resistance to antibiotics is an increasing concern worldwide and is associated mainly with uncontrolled usage of antimicrobials for treatment or as growth promoters in food animals (Barber et al., 2003). S. aureus resistant to methicillin is referred to as methicillin-resistant $S$. aureus (MRSA). Resistance to methicillin is mediated by the mecA gene, which encodes penicillinbinding protein 2a, (PBP2a) (Chambers, 2001 and Chambers, 1997) and carry insertion sites for mobile genetic elements that facilitate acquisition of resistance determinants to other antibiotics, because of its multidrug resistance pattern, MRSA is considered a public health concern (Malachowa and Deleo, 2010).

Compared with other metal oxide nanoparticles, $\mathrm{ZnO}$ NPs has comparatively inexpensive and relatively less toxic property exhibit excellent biomedical applications particularly as antibacterial agent [Xiong, 2013; Zhang and Ziong, 2015; Kim et al., 2017 and Mishrat et al., 2017). Zinc oxide nanoparticles ( $\mathrm{ZnO}-\mathrm{NPs}$ ) have been reported as an antimicrobial agent and of all the metal oxide nanoparticles studied so far exhibited the highest toxicity against pathogenic microorganisms, ZnO-NPs are such combinations that their purity is very high, their toxicity and pollution is very rare (Sangeetha et al., 2012). ZnO-NPs antibacterial activity directly correlates with their concentration and its activity is size dependent as reported by several studies, however, this dependency is also influenced by concentration of NPs (Sirelkhatim et al., 2015 and Wang et al., 2016). ZnO-NPs application as antimicrobial agent have been attributed to the induction of oxidative stress due to the formation of reactive oxygen species (ROS), that the formation of ROS is the main antibacterial mechanism of $\mathrm{ZnO}$ nanoparticles (Zhang et al., 2007 and Espitia et al., 2012), also to the membrane disruption as a result of accumulation of $\mathrm{ZnO}-\mathrm{NPs}$ therein, and internalization of nanoparticles followed by the release of antimicrobial ions $\left(\mathrm{Zn}^{+2}\right)$ (Sirelkhatim, et al 2015, Raghunath and Perumal, 2017). Scanning electron microscopical (SEM) and transmission electron microscopical (TEM) images characterize the size and shape of ZnO-NPs and also demonstrated that $\mathrm{ZnO}-\mathrm{NPs}$ firstly damage the bacterial cell wall, then penetrate, and finally accumulate in the cell membrane. They interfere with metabolic functions of the microbes causing their death. All the characteristics of the ZnO-NPs depend on their particle size, shape, concentration, and exposure time to the bacterial cell (Siddiqi et al., 2018). This study aimed to determine the antibiotic resistance profile of $S$. aureus and MRSA recovered from layer chicken 
and to evaluate the antibacterial activity of $\mathrm{ZnO}-\mathrm{NPs}$ against $S$. aureus isolates.

\section{Materials and Methods Collection of chicken samples}

A total number of 120-layer chicken samples obtained from 5 chicken farms in Assiut governorate. Samples were collected from hock joints and livers under aseptic conditions from diseased and freshly dead chickens from different private farms from different regions in Assiut Governorate, Egypt. Liver samples were collected from diseased and freshly dead birds while joint samples were obtained from birds suffering from lameness. The samples were then transferred to laboratory in an icebox.

\section{Isolation and identification}

The collected samples were inoculated into Tryptic soy broth (TSB) containing $70 \mathrm{mg} / \mathrm{ml} \mathrm{Na} \mathrm{Cl}$ and incubated at $37{ }^{\circ} \mathrm{C}$ for $24 \mathrm{~h}$. A loopful of the inoculated broth was sub cultured on Baird Parker agar medium at $37{ }^{\circ} \mathrm{C}$ for $48 \mathrm{~h}$. The typical suspected colonies of being staphylococci were sub cultured on Mannitol salt agar which used as selective as well as differential medium for isolation and identification of Staphylococci and tentatively identified according to morphological features, gram staining, catalase test, coagulase test (in tubes) according to the methods of Sullia and Santharan (1998) and Quinn et al. (2004).

Polymerase Chain Reaction (PCR) for identification of clfA and mecA genes

The coagulase positive staphylococcal isolates were tested for both molecular confirmation and the presence of both $c l f A$ and mecA genes in the Reference Laboratory for Veterinary Quality Control on Poultry Production in Animal Health Research Institute, Dokki, Giza, Egypt, as follow:

DNA extraction: DNA extraction from samples was performed using the QIAamp DNA Mini kit (Qiagen, Germany, GmbH) according to the manufacturer's recommendations.

PCR: Primers used were supplied from Metabion (Germany) and listed in table (1).

Table (1): Primers sequences, target genes, amplicon sizes and cycling conditions.

\begin{tabular}{|c|c|c|c|c|c|c|c|c|}
\hline \multirow[b]{2}{*}{$\begin{array}{c}\text { Target } \\
\text { gene }\end{array}$} & \multirow[b]{2}{*}{$\begin{array}{l}\text { Primers sequences } \\
\qquad\left(5^{\prime}-3^{\prime}\right)\end{array}$} & \multirow[b]{2}{*}{ 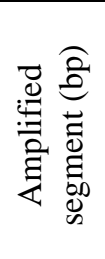 } & \multirow[b]{2}{*}{ 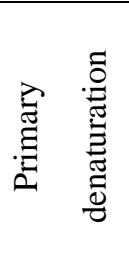 } & \multicolumn{3}{|c|}{ Amplification (35 cycles) } & \multirow{2}{*}{ 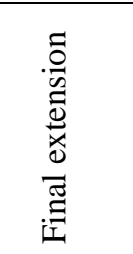 } & \multirow[b]{2}{*}{ 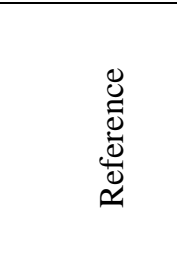 } \\
\hline & & & & 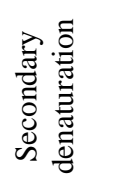 & 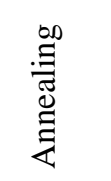 & 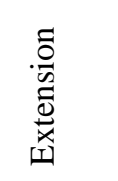 & & \\
\hline \multirow[b]{2}{*}{ meсA } & $\begin{array}{l}\text { GTA GAA ATG ACT } \\
\text { GAA CGT CCG ATA A }\end{array}$ & \multirow[b]{2}{*}{310} & \multirow[b]{2}{*}{$\begin{array}{l}94^{\circ} \mathrm{C} \\
5 \mathrm{~min} .\end{array}$} & \multirow[b]{2}{*}{$\begin{array}{l}94^{\circ} \mathrm{C} \\
30 \mathrm{sec} .\end{array}$} & \multirow[b]{2}{*}{$\begin{array}{l}50^{\circ} \mathrm{C} \\
30 \mathrm{sec} .\end{array}$} & \multirow[b]{2}{*}{$\begin{array}{l}72^{\circ} \mathrm{C} \\
30 \mathrm{sec} .\end{array}$} & \multirow[b]{2}{*}{$\begin{array}{l}72^{\circ} \mathrm{C} \\
7 \mathrm{~min} .\end{array}$} & \multirow[b]{2}{*}{$\begin{array}{l}\text { McClure et } \\
\text { al., } 2006\end{array}$} \\
\hline & $\begin{array}{l}\text { CCA ATT CCA CAT } \\
\text { TGT TTC GGT CTA A }\end{array}$ & & & & & & & \\
\hline \multirow{2}{*}{ clfA } & $\begin{array}{c}\text { GCAAAATCCAGCACA } \\
\text { ACAGGAAACGA }\end{array}$ & & \multirow[b]{2}{*}{$\begin{array}{l}94^{\circ} \mathrm{C} \\
5 \mathrm{~min} .\end{array}$} & \multirow{2}{*}{$\begin{array}{l}94^{\circ} \mathrm{C} \\
30 \mathrm{sec} .\end{array}$} & \multirow[b]{2}{*}{$\begin{array}{l}55^{\circ} \mathrm{C} \\
45 \mathrm{sec} .\end{array}$} & \multirow[b]{2}{*}{$\begin{array}{r}72^{\circ} \mathrm{C} \\
45 \mathrm{sec} .\end{array}$} & \multirow{2}{*}{$\begin{array}{l}72^{\circ} \mathrm{C} \\
10 \mathrm{~min} .\end{array}$} & \multirow[b]{2}{*}{$\begin{array}{l}\text { Mason et al. } \\
\quad 2001\end{array}$} \\
\hline & $\begin{array}{c}\text { CTTGATCTCCAGCCAT } \\
\text { AATTGGTGG }\end{array}$ & 638 & & & & & & \\
\hline
\end{tabular}




\section{PCR amplification:}

Primers were utilized in a $25-\mu 1$ reaction containing 12.5 $\mu 1$ of Emerald Amp Max PCR Master Mix (Takara, Japan), $1 \mu 1$ of each primer of 20 pmol concentration, $4.5 \mu 1$ of water, and $6 \mu 1$ of DNA template. The reaction was performed in an Applied biosystem 2720 thermal cycler.

\section{Analysis of the PCR Products:}

The products of PCR were analyzed using $1.5 \%$ agarose gel (Applichem, Germany, $\mathrm{GmbH}$ ) in 1x TBE buffer at room temperature using gradients of $5 \mathrm{~V} / \mathrm{cm}$. For gel analysis, $20 \mu \mathrm{l}$ of the products were loaded in each gel slot. A GelPilot 100bp DNA Ladder (Qiagen, Germany, GmbH) and generuler 100bp ladder (Fermentas, Thermo, Germany) were used to determine the fragment sizes. The gel was photographed by a gel documentation system (Alpha Innotech, Biometra).

\section{Determination of minimum inhibitory concentration (MIC):}

MICs of antibiotics were evaluated using the broth microdilution method in Mueller-Hinton broth (MHB) with an initial inoculum of $5 \times 10^{5}$ cells in non-treated polystyrene microtiter plates CC76727596; (CytoOne) in accordance with the Clinical and Laboratory Standards Institute (CLSI. 2007). Nine S. aureus were prepared in phosphate-buffered saline (PBS) until a McFarland standard of 0.5 was achieved. The solution was subsequently diluted 1:300 in Mueller-Hinton broth (MHB) to reach a starting inoculum of $5 \times 10^{5}$ colonyforming units $(\mathrm{CFU} / \mathrm{mL})$. Bacteria were then transferred to a 96-well microtiter plate. Antibiotics were added (in triplicate) to wells in the first row of the microtiter plate and then serially diluted along the vertical axis. Zinc oxide nanoparticles were diluted in $0.5 \mathrm{ml} \mathrm{HCL}(70 \%)$ and $0.5 \mathrm{ml}$ distilled water, the plates were incubated at $37^{\circ} \mathrm{C}$ for $22-24$ hours before the MIC was determined. MIC was defined as the lowest concentration which inhibited the visible growth of bacteria.

\section{Synthesis of the $\mathrm{ZnO} O \mathrm{NPS}$}

Zinc oxide nanoparticles synthesis were performed at Physics Department, Faculty of Science, Assiut University using procedures published by Othman et al. (2017, 2018).

\section{Characterization of ZnO-NPs:}

$\mathrm{ZnO}-\mathrm{NPs}$ were characterized by SEM to find out the surface morphology of synthesized zinc oxide nanoparticles and TEM image of synthesized ZnO-NPs was carried out to find out exact particle size of synthesized $\mathrm{ZnO}-\mathrm{NPs}$. These images were captured in The Electron Microscopy (EM) unit at Assiut University. (Figs 1,2)

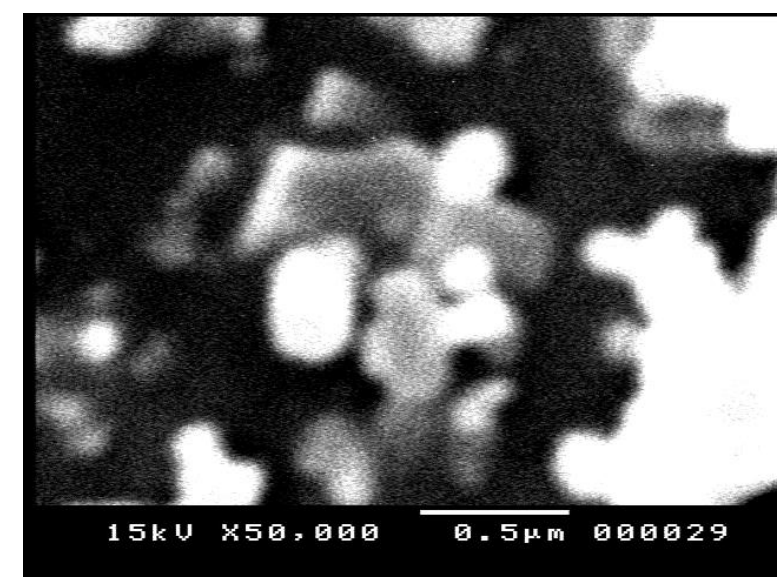

Fig 1: Scanning Electron Microscope (SEM) image of synthesized $\mathrm{ZnO}$ nanoparticles. Direct magnification: 50,000 x. HV=15 KV. SEM studies shows zinc oxide is in pure form and particles are white colored nanoparticles. 


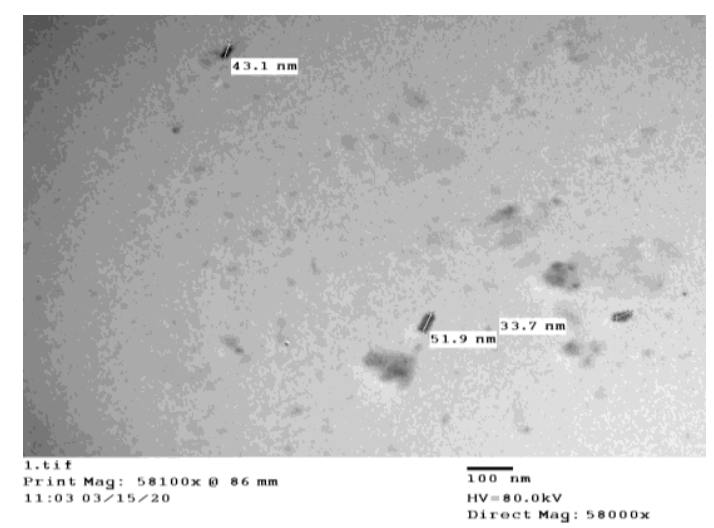

Fig 2: Transmission Electron Microscope (TEM) image of synthesized $\mathrm{ZnO}$ nanoparticles Direct magnification: 58,000 x. HV=80.0 KV. $\mathrm{ZnO}$ nanoparticles size are 33.7, 43.1 and 51.9

\section{Results \\ Prevalence of bacterial isolates:}

A total of 29 staphylococcal isolates were recovered from 120-layer samples (106 livers and 14 joints). The incidence of staphylococci in liver and joint samples was $24.52 \%$ and $21.42 \%$, respectively. Ten of the 29 isolates $(34.5 \%)$ were coagulase positive staphylococci (CPS) and 19 (65.5 $\%$ ) were coagulase negative staphylococci (CoNS) as demonstrated in table (2).

Table (2): Shows the prevalence of staphylococci in examined organs of layer chickens.

\begin{tabular}{|l|c|c|c|c|c|c|c|}
\hline $\begin{array}{l}\text { Examined } \\
\text { organs }\end{array}$ & $\begin{array}{c}\text { No. of } \\
\text { examined } \\
\text { organs }\end{array}$ & $\begin{array}{c}\text { No. of the } \\
\text { isolates }\end{array}$ & $\begin{array}{c}\text { Percentage } \\
(\%)\end{array}$ & $\begin{array}{c}\text { No. of } \\
\text { coagulase } \\
\text { positive } \\
\text { staphylococci }\end{array}$ & $\begin{array}{c}\text { Percentage } \\
(\%)\end{array}$ & $\begin{array}{c}\text { NO. of } \\
\text { coagulase } \\
\text { negative } \\
\text { staphylococci }\end{array}$ & $\begin{array}{c}\text { Percentage } \\
(\%)\end{array}$ \\
\hline Liver & 106 & 26 & 24.52 & 8 & 30.8 & 18 & 69 \\
\hline Joint & 14 & 3 & 21.42 & 2 & 66.7 & 1 & 33 \\
\hline Total & 120 & 29 & 24.16 & 10 & 34.5 & 19 & 65.5 \\
\hline
\end{tabular}

\section{$P C R$ results of detecting clfA and mecA genes in CPS isolates:}

In this approach, PCR was used to confirm S. aureus strains among 10 tested CPS isolates and to simultaneously detect methicillin resistant strains (MRSA). This assay targeted the clfA and $m e c A$ genes. Out of the 10 tested CPS strains, 10 were confirmed to be $S$. aureus as clfA gene was found, while 6 isolates only confirmed to be MRSA as they have mecA gene as shown in figures $(3,4)$. 


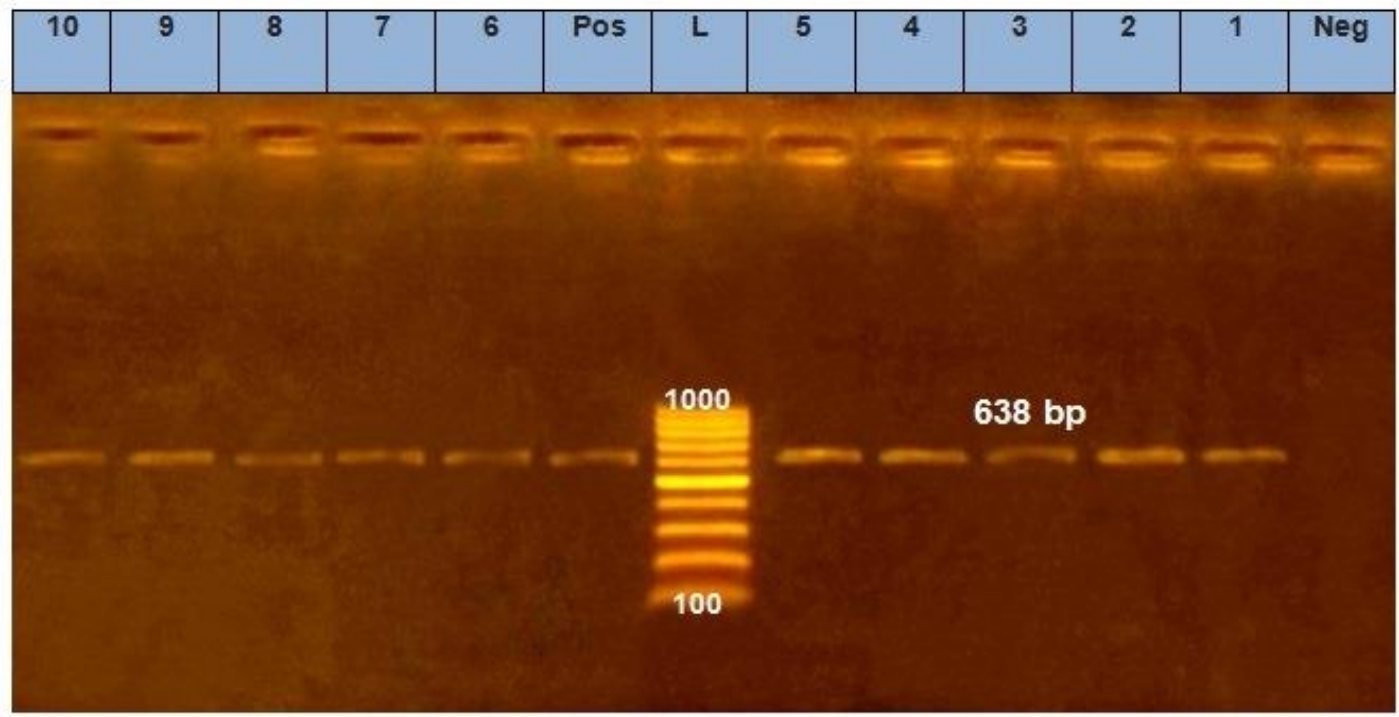

Fig 3: Agarose gel electrophoresis of products obtained by PCR for coagulase positive staphylococci strains to detect clfA gene at 638bp amplified product. Lan (L): 100 - 1000bp DNA ladder marker. Lanes (1-10): positive isolates at 638bp. Lane Pos: positive control. Lane Neg: negative control.

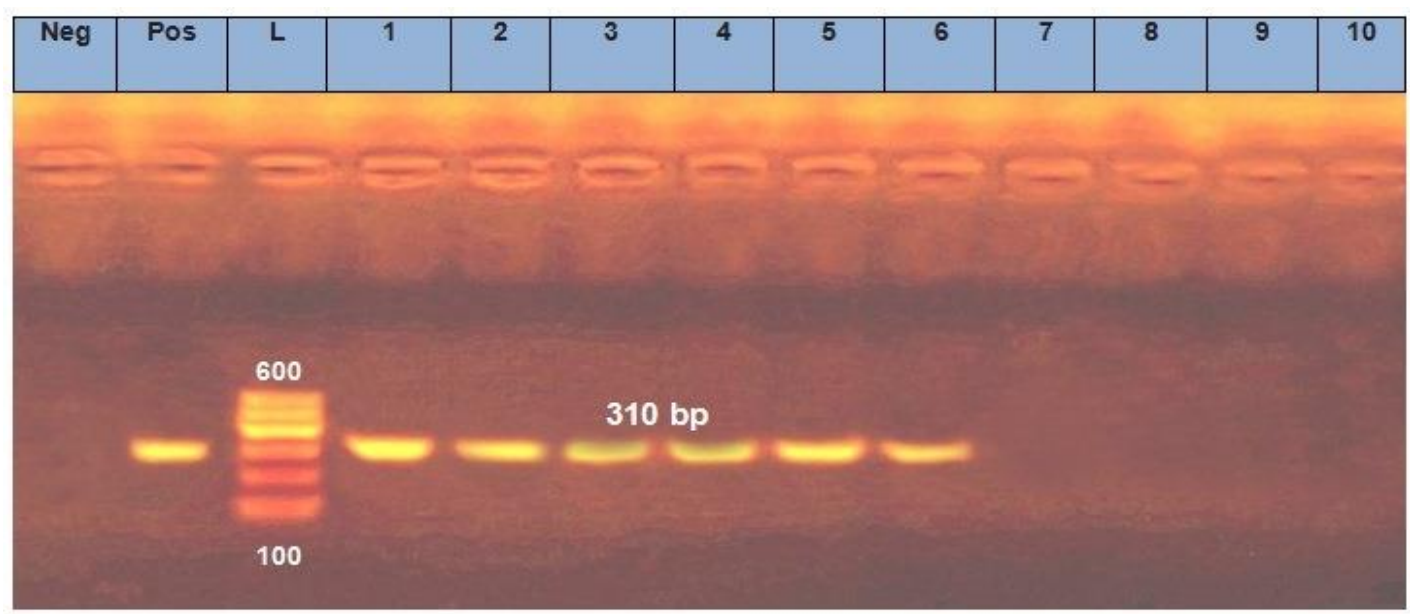

Fig 4: Agarose gel electrophoresis of products obtained by PCR for coagulase positive staphylococci strains to detect mecA gene at 310bp amplified product. Lan (L): 100-600bp DNA ladder marker. Lanes (1-6, numbered in the same sequence like Fig. 3): positive isolates at 310bp. Lanes (7-10): negative isolates at 310bp. Lane Pos: positive control. Lane Neg: negative control

\section{Minimum inhibitory concentration (MIC):}

Results revealed that the nine isolates demonstrated multiple antibiotic resistance patterns against most used antibiotics (table 3). Ciprofloxacin showed the lowest MIC against most of the $S$. aureus isolates, while ampicillin, lincomycin and colistin 
demonstrated the highest MIC against most S. aureus isolates. While some of the tested isolates demonstrated resistance against most tested antibiotics with an MIC >256, however, $\mathrm{ZnO}-\mathrm{NPs}$ showed the highest antibacterial effect against most multidrug resistant $S$. aureus isolates with an MIC ranging from $16-64 \mu \mathrm{g} / \mathrm{mL}$, as compared to all tested antibiotics.

Table (3): MIC $(\mu \mathrm{g} / \mathrm{mL})$ of selected antibiotics and $\mathrm{ZnO}-\mathrm{NPs}$ against nine $\mathrm{S}$. aureus isolates.

\begin{tabular}{|l|c|c|c|c|c|c|c|c|c}
\hline \multirow{2}{*}{$\begin{array}{c}\text { Antibacterial } \\
\text { agent }\end{array}$} & \multicolumn{70}{|c}{ S. aureus isolates } \\
\cline { 2 - 10 } & 1 & 2 & 3 & 4 & 5 & 6 & 7 & 8 & 9 \\
\hline Ampicillin & $>256$ & 64 & 256 & $>256$ & $>256$ & $>256$ & $>256$ & $>256$ & 256 \\
\hline Spiramycin & 64 & $<4$ & 256 & $<4$ & $<4$ & $<4$ & $<4$ & 32 & 32 \\
\hline Neomycin & $>256$ & 64 & 256 & 256 & 64 & 128 & $>256$ & 128 & 128 \\
\hline Ciprofloxacin & 128 & 64 & 64 & 4 & 64 & 4 & 64 & 256 & 256 \\
\hline Lincomycin & $>256$ & 128 & 256 & 256 & $>256$ & 256 & $>256$ & $>256$ & 256 \\
\hline Oxytetracycline & 256 & 16 & 256 & 256 & 64 & 128 & 32 & 256 & 128 \\
\hline Apramycin & 128 & 8 & 64 & 64 & 64 & 64 & 256 & 256 & $<4$ \\
\hline Florfenicol & 128 & $<4$ & 32 & $>256$ & 16 & 32 & 32 & 64 & 64 \\
\hline Colistin & $>256$ & 128 & $>256$ & $>256$ & $>256$ & 256 & 256 & $>256$ & $<4$ \\
\hline ZnO-NPs & 32 & 16 & 32 & 32 & 16 & 16 & 16 & 64 & 32 \\
\hline
\end{tabular}

\section{Discussion}

The S. aureus infection has become an increasingly grave problem in industrialized poultry farming, and create major human and animal health problems globally (Lowder et al., 2009). The relatively high rate of isolation of S. aureus $(34.5 \%)$, in the present study, from layer chickens comes in accordance with previous findings of Mamza et al. (2010) and Mamza et al. (2019) who recorded $35 \%$ and $31.5 \%$ carriage of $S$. aureus in layer chickens, Otalu et al. (2011) who recorded 38.5\% prevalence of $S$. aureus from layer farms and Bounar-Kechih et al. (2018) who reported $42 \%$ in laying hens. However, Onaolapo et al., (2017), isolated S. aureus at higher prevalence $(51.2 \%)$ from broilers and layers.

The virulence of $S$. aureus is accompanied by the presence of virulence genes ( $c l f A$ and $c l f B$ ) that encode proteins with affinity to fibrinogen i.e., clumping factors A and B (Momtaz, 2013 and Erfan and Marouf, 2015). The last authors detected clfA virulence gene in $76.82 \%$ and $100 \%$ of their samples, respectively. These findings simulate our PCR results where all coagulase positive isolates $(100 \%)$ demonstrated clfA gene. However, six isolates out of ten $(60 \%)$, in the present study, confirmed to be MRSA as they have $m e c A$ gene. The current high prevalence of $m e c A$ gene could be the cause of multi-drug resistance of the MRSA strains. These results agree with those of Bounar-Kechih et al. (2018) who recorded 57\% MRSA in laying hens and at the same time they found that MRSA strains isolated from poultry showed cross-resistance to aminoglycosides, macrolides, sulphonamides, fluoroquinolones and cyclins.

In the current study, the patterns of antibiotics resistances to the commonly used antibiotics in poultry practice against $S$. aureus comes in agreement with those of Otalu et al. (2011), Onaolapo et al., (2017) and Mamza et al. (2019), who reported multiple resistances across families of antibiotics to isolates of $S$. aureus isolated from chickens. These multiple drug resistances can limit therapeutic options in cases of $S$. aureus infections. $\mathrm{ZnO}$ is generally recognized as safe substance by the US Food and Drug Administration (Rasmussen et al., 2010). As an alternative antibacterial, $\mathrm{ZnO}-\mathrm{NPs}$ were used in this study against $S$. aureus isolated from layer chickens to evaluate its antibacterial activity. We found that all obtained isolates were highly sensitive to $\mathrm{ZnO}-\mathrm{NPs}$ compared to all used antibiotics in the present investigation. ZnO-NPs sizing less than $100 \mathrm{~nm}(33.7,43.1$ and $51.9 \mathrm{~nm})$ effectively inhibited the growth of all $S$. aureus isolates, a result which concord to that found by Yamamoto (2001) and 
Raghupathi et al. (2011), who believed that ZnO-NPs with smaller size (higher specific surface areas) showed the highest antibacterial activity against $S$. aureus and E. coli. Zhang et al. (2007), reported that ZnO-NPs of smaller sizes can easily penetrate into bacterial cell membranes due to their large interfacial area, thus enhancing their antibacterial efficiency. This has been also confirmed by Iram et al. (2015) who found that higher concentrations and $\leq 50 \mathrm{~nm}$ size of $\mathrm{ZnO}$ NPs have efficiently inhibited the growth of Gram-positive organism such as $S$. aureus. MIC of $1 \mathrm{mg} / \mathrm{mL}$ was the concentration that efficiently inhibited the growth of $S$. aureus in our study, which agrees with what has been reported by Reddy et al. (2007). The last authors recorded concentration $1 \mathrm{mg}$ $/ \mathrm{mL}$ of ZnO-NPs for S. aureus and $3.4 \mathrm{mg}$ $/ \mathrm{mL}$ for E. coli. However, Emami-Karvani and Chehrazi, (2011) found that 1.5 and 3.1 $\mathrm{mg} \mathrm{mL}-1$ inhibited $S$. aureus and E. coli, respectively.

\section{Conclusions}

The current study provides a foresight into the role of $\mathrm{ZnO}-\mathrm{NPs}$ as an effective alternative antibacterial treatment and control for $S$. aureus infections.

\section{Competing interest}

The authors have declared that no competing interest exists.

\section{References}

Andreasen CB (2003). Staphylococcosis. In: Saif YM, 11th ed. Diseases of poultry, Iowa State Press: 797-804.

Barber DA, Miller GY, McNamara PE (2003). Models of antimicrobial resistance and foodborne illness: Examining assumptions and practical applications. Journal of Food Protection, 66:700-709.

Bounar-Kechih S, Hamdi MT, Aggad H, Meguenni N, Cantekin Z (2018). Carriage methicillin-resistant Staphylococcus aureus in poultry and cattle in northern Algeria. Veterinary Medicine International, 5 pages, available at: https://doi.org/10.1155/2018/46361 $\underline{21}$

Chambers HF (2001). The Changing Epidemiology of Staphylococcus aureus? Emerging Infectious Diseases, 7(2):178-82.

Chambers HF. (1997): Methicillin resistance in staphylococci: Molecular and biochemical basis and clinical implications. Clinical Microbiology Reviews, 10:781791.

CLSI, Clinical and Laboratory Standards Institute (2007). Methods for dilution antimicrobial susceptibility tests for bacteria that grow aerobically; approved standard $\mathrm{M}$ A7. CLSI, Wayne, PA.

Emami-Karvani Z, Chehrazi, P (2011). Antibacterial activity of $\mathrm{ZnO}$ nanoparticle on gram-positive and gram-negative bacteria. African Journal of Microbiology Research, 5(12): 1368-1373.

Erfan AM and Marouf SH (2015). Biofilmproducing Staphylococcus aureus screening in poultry farms and abattoirs. Journal of Animal and Veterinary Advances, 14 ( 10): 273279. 
Espitia, PJP, Soares NFF, Coimbra JSR, Andrade NJ, Cruz RS, Medreiros EAA (2012). Zinc oxide nanoparticles: synthesis, antimicrobial activity and food packaging applications. Food and Bioprocess Technology, 5: 14471464.

Iram S, Nadhman A, Akhtar N, Hameed A, Zulfiqar Z, Yameen MA (2015). Potentiating efficacy of antibiotic conjugates with zinc oxide nanoparticles against clinical isolates of staphylococcus aureus. Digest Journal of Nanomaterials and Biostructures, 10 (3): 901-914

Kim S, Lee SY, Cho HJ (2017). Doxorubicin-wrapped zinc oxide nanoclusters for the therapy of colorectal adenocarcinoma. Nanomaterials, 7 (11): 354.

Lowder BV, Guinane CM, Zakour NL, Weinert LA, Conway-Morris A, Robyn A, Cartwright RA, Simpson AJ, Rambaut A, Nübel U, Fitzgerald JR (2009). Recent Human-toPoultry Host Jump, Adaptation, and Pandemic Spread of Staphylococcus aureus. Proceedings of the National Academy of Sciences, 106: 1954519550.

Malachowa N, DeLeo FR (2010). Mobile genetic elements of Staphylococcus aureus. Cellular and Molecular Life Sciences, 67: 3057-3071.

Mamza SA, Egwu GO, Mshelia GD (2010). Antibiotic susceptibility patterns of beta-lactamase-producing

Escherichia coli and Staphylococcus aureus isolated from chickens in Maiduguri (Arid zone), Nigeria. Veterinary Archives, 80 (2): 283-297.

Mamza SA, Geidam YA, Mshelia GD, Egwu GO (2019). Carriage, Antibiotic Susceptibility, and BetaLactamase Production Profiles of Coagulase-Positive Staphylococcus aureus Isolated from Chickens in North-Eastern Nigeria. Annals of Clinical and Medical Microbiology, 4(1): 1022-1031.

Mason WJ, Blevins JS, Beenken K, Wibowo N, Ojha N, Smeltzer MS (2001) multiplex PCR protocol for the diagnosis of staphylococcal infection. Journal of Clinical Microbiology, 39(9): 3332-3338.

McClure J-A, Conly JM, Lau V, Elsayed S, Louie T, Hutchins W, Zhang $\mathrm{K}$ (2006). Novel multiplex PCR assay for detection of the staphylococcal virulence marker Panton-Valentine leukocidin genes and simultaneous discrimination of methicillinsusceptible from -resistant staphylococci. Journal of Clinical Microbiology, 44: 1141-114.

Mishra PK, Mishra H, Ekielski A, Talegaonkar S, Vaidya B (2017) Zinc oxide nanoparticles: a promising nanomaterial for biomedical applications. Drug Discovery Today, 22 (12): 18251834.

Momtaz H (2013). Virulence genes and antimicrobial resistance profiles of Staphylococcus aureus isolated from chicken meat in Isfahan province, Iranian Journal of Applied Poultry Research, 22 (4): 913-921. https://doi.org/10.3382/japr.201200673. 
Onaolapo JA, Igwe JC, Bolaji RO, Adeshina GO, Parom SK (2017). Antibiotics susceptibility profile of Staphylococcus aureus isolated from poultry birds in Kaduna, Nigeria. Journal of Clinical Microbiology and Antimicrobials, 1: 101-106.

Otalu O Jr, Kabir JJ, Okolocha EC, Umoh VJ (2011). Multi-drug resistant coagulase positive Staphylococcus aureus from live and slaughtered chickens in Zaria, Nigeria. International Journal of Poultry Science, 10: 871-875.

Othman AA, Osman MA, Abd-Elrahim AG (2018). The effect of milling time on structural, optical and photoluminescence properties of ZnO nanocrystals. Optik, 156: 161168.

https://doi.org/10.1016/j.ijleo.2017. 11.037

Othman AA, Osman MA, Ibrahim EMM, Ali MA (2017). Sonochemically synthesized $\mathrm{ZnO}$ nanosheets and nanorods: Annealing temperature effects on the structure, and optical properties. Ceramics International, 43 (1): 527-533. https://doi.org/10.1016/j.ceramint. 2 $\underline{016.09 .189}$

Quinn PJ, Carter ME, Markey B, carter GR (2004). "Clinical Veterinary Microbiology". Mosby, Elsevier Limited, London.

Raghunath A, Perumal E (2017). Metal oxide nanoparticles as antimicrobial agents: a promise for the future. International Journal of Antimicrobial Agents, 49: 137-152. https://doi.org/10.1016/j.ijantimica g.2016.11.011

Raghupathi KR, Koodali RT, Manna AC (2011). Size-dependent bacterial growth inhibition and mechanism of antibacterial activity of zinc oxide nanoparticles. Langmuir: The ACS Journal of Surfaces and Colloids, 27(7): $\quad$ 4020-4028. doi:10.1371/journal.pone.0085981

Rasmussen JW, Martinez E, Louka P, Wingett DG (2010). Zinc oxide nanoparticles for selective destruction of tumor cells and potential for drug delivery applications. Expert Opinion on Drug Delivery, 7 (9): 1063-1077.

Reddy KM, Feris K, Bell J, Wingett DG, Hanley C, Punnoose A (2007). Selective toxicity of zinc oxide nanoparticles to prokaryotic and eukaryotic systems. Applied Physics Letters, 90(21): 21390212139023. doi:10.1063/1.2742324

Sangeetha G, Rajeshwari S, Venckatesh R (2012). Green synthesized $\mathrm{ZnO}$ nanoparticles against bacterial and fungal pathogens. Progress in Natural Science: Materials International, 22(6): 693-700.

Siddiqi KS, Ur Rahman A, Tajuddin, Husen A (2018). Properties of zinc oxide nanoparticles and their activity against microbes. Nanoscale Research Letters, 13(1): 141.

Sirelkhatim A, Mahmud S, Seeni A, Kaus NHM, Ann LC, Bakhori SKM, Mohamad D (2015). Review on zinc oxide nanoparticles: Antibacterial activity and toxicity mechanism. Nano-Micro Letters, 7, 219- 
242. https://doi.org/10.1007/s40820 -015-0040-x [ Links ]

Sullia SB, Shantharam S (1998). General Microbiology. 1st. Ed. Oxford \& IBH Publishing Co. New Delhi, pp 549-562.

Wang C, Lu J, Zhou L, Li J, Xu J, Li, Zhang L, Zhong X, Wang T (2016). Effects of long-term exposure to zinc oxide nanoparticles on development, zinc metabolism and biodistribution of minerals ( $\mathrm{Zn}, \mathrm{Fe}, \mathrm{Cu}, \mathrm{Mn}$ ) in mice. PLoS One, 11(10): e0164434. doi: 10.1371/journal.pone.0164434.

Xiong HM (2013). ZnO nanoparticles applied to bioimaging and drug delivery. Advanced Materials, 25 (37): 5329-5335.
Yamamoto O (2001). Influence of particle size on the antibacterial activity of zinc oxide. International Journal of Inorganic Materials, 3(7): 643-646. doi:10.1016/S14666049(01)00197-0

Zhang L, Jiang Y, Ding Y, Povey M, York $D$ (2007). Investigation into the antibacterial behaviour of suspensions of $\mathrm{ZnO}$ nanoparticles ( $\mathrm{ZnO}$ nanofluids). Journal of Nanoparticle Research, 9(3): 479489.

Zhang ZY, Xiong HM (2015). Photoluminescent $\mathrm{ZnO}$ nanoparticles and their biological applications. Materials, 8 ( 6): 3101-3127. 